\title{
KOMPONEN KIMIA MINYAK ATSIRI DAUN JERUK PURUT (Citrus hystrix) DAN BIOAKTIVITASNYA TERHADAP BAKTERI Salmonella typhi DAN Salmonella Typhimurium
}

\author{
Tri Oktania Simanjuntak*, Yeni Mariani, Fathul Yusro \\ Prodi Kehutanan, Fakultas Kehutanan, Universitas Tanjungpura \\ Jl. Daya Nasional Pontianak 78124 \\ "Email: trioctania3121@gmail.com
}

\begin{abstract}
Abstrak
Jeruk purut (Citrus hystrix) memiliki potensi untuk dikembangkan sebagai tanaman agroforestri karena sebagai tanaman penghasil minyak atsiri dan dapat digunakan sebagai bahan obat, salah satunya sebagai antibakteri. Komponen kimia minyak atsiri yang terkandung dalam suatu tanaman sangat bergantung pada tempat tumbuhnya dan hal tersebut tentu akan menentukan tingkat aktivitasnya sebagai antibakteri. Tujuan penelitian yaitu mengidentifikasi komponen kimia minyak atsiri daun jeruk purut yang berasal dari Kalimantan Barat dan bioaktivitasnya dalam penghambatan pertumbuhan bakteri Salmonella typhi dan Salmonella Typhimurium. Daun jeruk purut dilakukan penyulingan dengan metode uap dan minyak atsiri yang dihasilkan diidentifikasi komponen kimianya menggunakan GC MS (Gas chromatography-mass spectrometry). Pengujian bioaktivitasnya terhadap bakteri S. typhi dan S. typhimurium menggunakan empat taraf konsentrasi yaitu 0,5; 1; 5 dan 10\%. Sebanyak 12 senyawa teridentifikasi dalam minyak atsiri daun jeruk purut dengan 5 senyawa utamanya adalah sitronellal (80,83\%), 2,6-oktadiene (5,36\%), bicyclo (3.1.0) hexane (3,79\%), sitronellol (3,48\%) dan linalol (2,57\%). Pertumbuhan bakteri S. typhi atau S. Typhimurium dapat terhambat oleh minyak daun jeruk purut dan penghambatannya pada konsentrasi $10 \%$ tergolong lemah yaitu sebesar 1,17 $\mathrm{mm}$ dan 1,42 $\mathrm{mm}$.
\end{abstract}

Kata kunci: Antibakteri, jeruk purut, minyak atsiri, Salmonella typhi, Salmonella Typhimurium

\section{PENDAHULUAN}

Minyak atsiri kini menjadi salah satu dari sekian banyak produk HHBK (hasil hutan bukan kayu) yang mempunyai potensi besar sebagai sumber pendapatan atau mata pencarian bagi masyarakat sekitar hutan. Hal ini karena tingginya tingkat kebutuhan terhadap minyak atsiri dan Indonesia menjadi negara pengekspor minyak atsiri terbesar ke-9 didunia dengan besaran nilai ekspor USD 123 juta pada tahun 2013 (Rosiana dkk., 2017). Kebutuhan yang besar tersebut harus didukung dengan ketersediaan bahan baku yang cukup, dan jika hanya mengandalkan dari bahanbahan yang diambil langsung atau tumbuh liar dihutan maka akan sangat sulit untuk kontinyuitas produksinya kedepan. Oleh karena itu, proses pembudidayaan terhadap jenis atau spesies tanaman yang potensial sebagai sumber utama bahan baku minyak atsiri penting untuk dilakukan, dan hal tersebut didukung oleh Permenhut No. P.35/Menhut-II/2007 bahwa HHBK bukan hanya produk nabati dan hewani yang langsung diambil dari hutan tetapi juga dapat dalam bentuk produk turunan maupun tanaman budidayanya selain kayu. Berdasarkan hal tersebut maka tanaman-tanaman yang potensial sebagai penghasil minyak atsiri perlu untuk dilakukan kajian yang pada akhirnya diharapkan dapat dikembangkan dan dibudidayakan disekitar hutan atau menjadi bagian dari agroforestri.

Beragam spesies tanaman telah dimanfaatkan sebagai utama sumber bahan baku minyak atsiri antara lain cendana, cengkeh, gaharu, gandapura, kayu putih, kayu lawang, kayu manis, kayu massoi, pinus, sereh wangi dan jeruk purut (Wahyudi, 2013). Masyarakat di Kalimantan Barat mengenal tanaman jeruk purut (Citrus hystrix) sebagai tanaman budidaya yang banyak dimanfaatkan daun ataupun buahnya untuk bumbu masakan. Beberapa peneliti telah menunjukkan adanya manfaat lain dari jeruk purut yaitu sebagai obat-obatan, antara lain untuk anti kanker pankreas (Sun dkk., 2018), antioksidan (Warsito dkk., 2017), antidandruff (Tanzil dkk., 2017), kardioprotektif, hepatoprotektif (Putri dkk., 2013) dan antibakteri (Yuliani dkk., 2011; Warsito dkk., 2017; Borusiewicz dkk., 2017).

Sifat antibakteri yang dimiliki oleh minyak atsiri jeruk purut antara lain terhadap Acinetobacter baumannii (Borusiewicz dkk., 2017) Staphylococcus aureus, Escherichia coli 
(Yuliani dkk., 2011; Warsito dkk., 2017), Klebsiella pneumoniae (Jamaluddin dkk., 2017), Salmonella typhi, Shigella spp., Salmonella arizonae, Serratia spp., Morganella morganii, Citrobacter spp., Plesiomonas shigelloides, Providencia spp., Yersinia enterocolitica dan Enterobacter spp (Sreepian dkk., 2019). Potensi antibakteri ini dikarenakan adanya komponen kimia bioaktif yang terdapat dalam minyak atsiri jeruk purut seperti monoterpen hidrokarbon, monoterpene teroksigenasi, sesquiterpen hidrokarbon, D-limonen, $\beta$-pinen, dan sabinen (Sreepian dkk., 2019). Namun, komponen kimia minyak atsiri yang terkandung dalam suatu tanaman sangat bergantung pada tempat tumbuhnya (Nur dkk., 2019) dan hal tersebut tentu akan menentukan tingkat aktivitasnya sebagai antibakteri.

Beberapa sifat antibakteri minyak jeruk purut telah dilaporkan, namun referensi mengenai kemampuannya dalam penghambatan bakteri Salmonella typhi dan Salmonella Typhimurium hingga saat ini masih terbatas. Kedua bakteri tersebut dikenal sebagai penyebab penyakit demam tifoid atau typus pada manusia (Santos dkk., 2003; Cita, 2011). Penelitian ini bertujuan untuk mengidentifikasi komponen kimia minyak atsiri daun jeruk purut dan aktivitasnya sebagai penghambat pertumbuhan bakteri S. typhi dan S. Typhimurium.

\section{METODOLOGI}

Penelitian ini dilakukan di tiga laboratorium yaitu Lab. Kimia MIPA Universitas Tanjungura, Lab. Kesehatan Daerah Jakarta dan Unit Lab. Kesehatan Pontianak. Peralatan yang digunakan adalah seperangkat alat destilasi uap, GC MS (Gas chromatography-mass spectrometry), mikropipet dan cawan petri. Bahan yang dipergunakan antara lain daun jeruk purut yang diambil dari pekarangan rumah warga di Jalan Purnama Pontianak, DMSO (Dimethyl sulfoxide), MHA (Mueller Hinton Agar), amoksilin, bakteri S. typhi dan S. Typhimurium.

\section{a. Penyulingan minyak atsiri dan identifikasi komponen kimia}

Proses penyulingan daun jeruk purut dilakukan dengan metode penyulingan uap. Sebanyak $4 \mathrm{~kg}$ daun dimasukkan kedalam ketel pemasak yang sebelumnya telah diisi dengan air hingga batas saringan. Proses penyulingan dilakukan dengan memanaskan ketel selama 5 jam dan selama proses tersebut dihasilkan uap yang akan mengembun dikondensor. Embun (hidrosol) tersebut selanjutnya dialirkan keluar dan ditampung dalam wadah separator. Hidrosol dan minyak yang dihasilkan selanjutnya dilakukan proses pemisahan dengan mengambil minyak dalam separator dan memasukkannya kedalam botol vial. Minyak tersebut ditambahkan dengan MgSO4 anhidrat, dan dilakukan pengocokan hingga terpisah antara air dan minyak. Minyak atsiri yang diperoleh selanjutnya dilakukan identifikasi komponen kimianya menggunakan GC MS (Gas chromatography-mass spectrometry).

\section{b. Bioaktivitas antibakteri}

Pengujian ini menggunakan empat taraf konsentrasi minyak atsiri daun jeruk purut yaitu $0,5 \%$, $1 \%, 5 \%$ dan $10 \%$. Selain itu digunakan pula kontrol negatif (DMSO) dan kontrol positif amoksilin $10 \mu \mathrm{g})$. Tahap awal penelitian yaitu dengan meneteskan $20 \mu \mathrm{L}$ minyak atsiri, DMSO dan amoksilin pada kertas cakram (diameter $6 \mathrm{~mm}$ ) hingga terserap secara sempurna. Selanjutnya kertas cakram tersebut diletakkan pada media MHA yang sebelumnya telah diswabkan bakteri $S$. typhi atau $S$. Typhimurium dengan tingkat kekeruhan $3 \times 10^{8} \mathrm{CFU} / \mathrm{ml}$ (standar Mc. Farland 1). Tahap berikutnya yaitu dengan melakukan proses inkubasi $\left(37^{\circ} \mathrm{C} ; 24\right.$ jam). Tahap akhir adalah dengan mengukur diameter penghambatan yang terbentuk dan hasilnya dianalisis menggunakan oneway anova pada perangkat SPSS 22.

\section{HASIL DAN PEMBAHASAN}

\section{a. Komponen kimia minyak atsiri daun jeruk purut}

Hasil dari penelitian ini diketahui bahwa minyak daun jeruk purut mengandung 12 senyawa dengan beberapa senyawa utamanya antara lain sitronellal $(80,83 \%)$, 2,6-oktadiene $(5,36 \%)$, bicyclo (3.1.0) hexane (3,79\%), sitronellol (3,48\%) dan linalol (2,57\%) (Gambar 1, Tabel 1). Jika dibandingkan dengan hasil penelitian Warsito dkk., (2017) didaerah Tulung Agung Jawa Timur yang menunjukkan adanya 14 komponen kimia, maka minyak daun jeruk purut yang dihasilkan dari Pontianak tidak jauh berbeda dari segi jumlah senyawanya.

Jika dilihat dari komponen utamanya, senyawa sitronellal merupakan senyawa utama yang terkandung dalam minyak daun jeruk purut dengan persentase kandungan 80,83\% dari keseluruhan 
senyawa yang ada. Hal yang sama juga ditunjukkan oleh peneliti lain bahwa senyawa utama dari jeruk purut adalah sitronellal (Mayasari dkk., 2013; Lestari dkk., 2015; dan Warsito dkk., 2017), namun berbeda dari segi persentase kandungan senyawanya. Jika dibandingkan dengan didaerah Kubu Raya Kalimantan Barat, komponen sitronellal yang diperoleh dalam penelitian ini lebih tinggi, namun jika dikomparasikankan dengan daerah Tulung Agung Jawa Timur tergolong lebih rendah walaupun secara persentase perbedaannya tidak terlalu besar (Tabel 2).

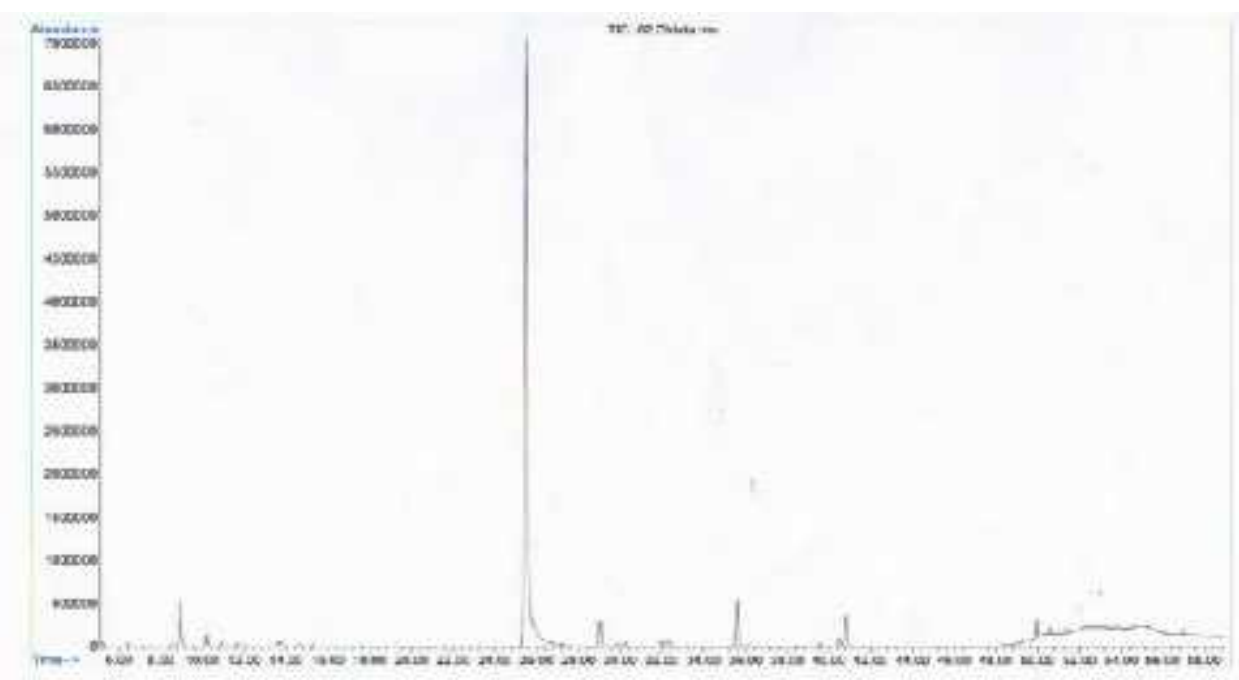

Gambar 1. Kromatogram GC MS (Gas chromatography-mass spectrometry) minyak daun jeruk purut.

Tabel 1. Komponen kimia minyak atsiri daun jeruk purut

\begin{tabular}{ccccc}
\hline No. & $\begin{array}{c}\text { Waktu Retensi } \\
(\mathbf{R t})\end{array}$ & Nama Senyawa & \% Area & $\begin{array}{c}\text { Similarity Index } \\
\text { (SI) }\end{array}$ \\
\hline 1 & 8,906 & Bicyclo (3.1.0) hexane & 3,79 & 96 \\
2 & 10,198 & Beta myrcene & 0,82 & 96 \\
3 & 25,535 & Sitronellal & 80,83 & 94 \\
4 & 25,987 & 6-oktenal & 0,17 & 97 \\
5 & 26,039 & 6-oktenal & 0,11 & 97 \\
6 & 29,022 & Linalol & 2,57 & 97 \\
7 & 32,000 & Terpinen-4-ol & 0,69 & 96 \\
8 & 35,606 & 2,6-oktadiene & 5,36 & 98 \\
9 & 40,525 & 2,6-oktadiene-1-ol & 0,80 & 91 \\
10 & 40,811 & Sitronellol & 3,48 & 98 \\
11 & 49,963 & Tran-nerolidyl formate & 0,82 & 91 \\
12 & 56,973 & Benzene & 0,56 & 95 \\
\hline
\end{tabular}

Selain sitronellal, senyawa yang ada namun dalam persentase yang kecil dan memiliki kesamaan dengan daerah lain adalah linalool. Senyawa linalool yang didapat dari penelitian ini sebesar 2,57\%, lebih kecil jika dikomparasikan dengan hasil yang diperoleh oleh Warsito dkk., (2017) dan Lestari dkk., (2015). Dari 5 komponen utama, terdapat 3 komponen berbeda dengan hasil penelitian Warsito dkk., (2017) dan 2 komponen dengan penelitian Lestari dkk., (2015) (Tabel 2). Adanya perbedaan komposisi dan persentase senyawa yang dihasilkan dalam penelitian ini menguatkan teori yang sudah ada bahwa perbedaan tempat tumbuh berpengaruh terhadap mutu minyak atsiri yang dihasilkan (Wahyudi, 2013; Nur dkk., 2019).

Adanya kesamaan senyawa utama (sitronellal dan linalool) yang dihasilkan dan tingkat persentasenya yang tidak terlalu besar dengan daerah lain khususnya Tulung Agung Jawa Timur maka minyak daun jeruk purut yang diproduksi dari daerah Pontianak sangat potensial untuk dikembangkan dan dibudidayakan disekitar hutan atau menjadi bagian dari agroforestri. Selain itu, 
adanya senyawa-senyawa tersebut memungkinkannya untuk digunakan sebagai antibakteri alami. Selanjutnya, untuk membuktikan kemampuan minyak atsiri daun jeruk purut ini sebagai antibakteri maka dilakukan pengujian terhadap bakteri-bakteri patogen, diantaranya adalah $S$. typhi dan $S$. typhimurium.

Tabel 2. Perbandingan komponen kimia utama minyak atsiri daun jeruk purut dengan daerah lain

\begin{tabular}{|c|c|c|c|}
\hline No. & $\begin{array}{c}\text { Pontianak } \\
\text { Kalimantan Barat } \\
\text { (Hasil penelitian) }\end{array}$ & $\begin{array}{c}\text { Tulungagung } \\
\text { Jawa Timur } \\
\text { (Warsito et al. 2017) } \\
\end{array}$ & $\begin{array}{c}\text { Kubu Raya } \\
\text { Kalimantan Barat } \\
\text { (Lestari et al. 2015) }\end{array}$ \\
\hline 1 & Sitronellal $(80,83 \%)$ & Sitronellal $(85,97 \%)$ & Sitronellal $(65,63 \%)$ \\
\hline 2 & 2,6-oktadiene $(5,36 \%)$ & Linalool $(3,46 \%)$ & Beta.-Sitronelol $(6,42 \%)$ \\
\hline 3 & Bicyclo (3.1.0) hexane $(3,79 \%)$ & Sabinene (s) $(2,79 \%)$ & Linalool L $(4,56 \%)$ \\
\hline 4 & Sitronellol $(3,48 \%)$ & Citronelyl acetate $(2,77 \%)$ & 2,6-Oktadiene $(2,31 \%)$ \\
\hline 5 & Linalol $(2,57 \%)$ & Caryophylene $(1,77 \%)$ & $\begin{array}{l}\text { 6,7-Epoksi-3,7-dimetiloktanal } \\
(2,06 \%)\end{array}$ \\
\hline
\end{tabular}

\section{b. Bioaktivitas terhadap bakteri S. typhi dan S. typhimurium}

Pengujian yang dilakukan dalam penelitian ini menggunakan beberapa perlakuan yaitu

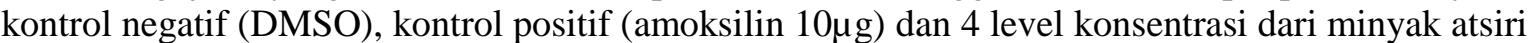
daun jeruk purut $(0,5 \%, 1 \%, 5 \%$ dan $10 \%)$. Zona bening yang terbentuk diukur dan dianalisa daya hambatnya (Gambar 2, 3 dan 4). Kontrol negatif (DMSO digunakan sebagai pelarut untuk pembuatan konsentrasi uji) tidak terbentuk zona bening pada kedua jenis bakteri uji. Tidak terbentuknya hambatan pada pengujian kontrol negatif menunjukkan bahwa pelarut ini tidak menunjukkan respon hambatan terhadap pertumbuhan bakteri, dan hal serupa juga dilaporkan oleh Wei Su dkk., (2015) dan Hua Li (2019).

Pada penelitian ini, kontrol positif yaitu amoksilin menunjukkan zona bening pada bakteri $S$. typhi $(12 \mathrm{~mm})$ dan $S$. Typhimurium $(13,17 \mathrm{~mm})$. Besarnya daya hambat yang ditunjukkan oleh amoksilin dinilai mampu untuk menghambat pertumbuhan bakteri S. typhi dan S. Typhimurium. Amoksilin merupakan antibiotik semi-sintetis yang bersifat stabil terhadap asam merupakan golongan antibiotik laktam yang telah dilaporkan menunjukkan keefektifan dalam menangani infeksi yang disebabkan oleh berbagai macam bakteri, baik itu Gram positif maupun negatif (Kaur, 2011). Mekanisme kerja dari amoksilin adalah menghambat terbentuknya membran sel dari bakteri yang selanjutnya akan menyebabkan terurainya materi genetik dari bakteri tersebut yang akan berujung pada kematian bakteri (Sandika, 2017).

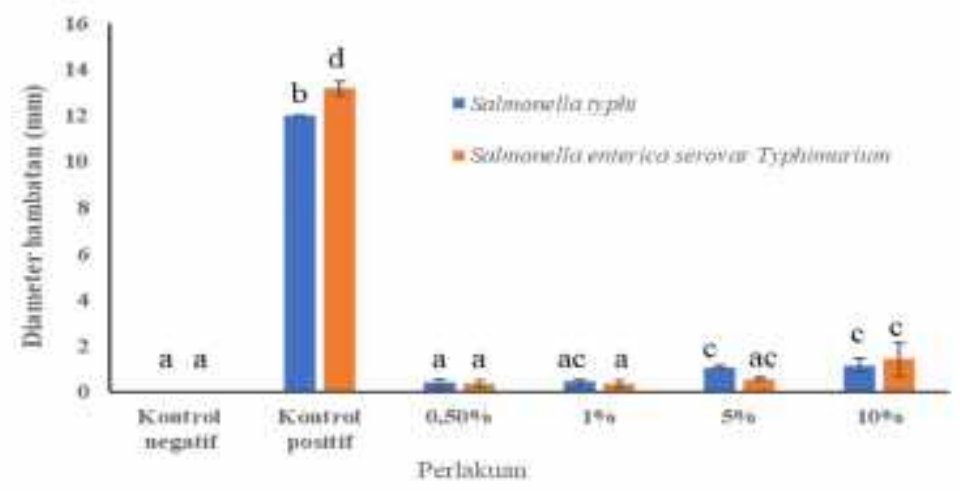

Keterangan: Perbedaan yang nyata pada tingkat kepercayaan 95\% ditunjukkan oleh adanya perbedaan huruf dari nilai rerata

Gambar 2. Diameter hambatan \pm SD pertumbuhan bakteri $S$. typhi dan $S$. typhimurium oleh minyak daun jeruk purut

Penggunaan konsentrasi minyak atsiri daun jeruk terendah pada pengujian bakteri $S$. typhi maupun S. Typhimurium menunjukkan daya hambat yang tidak jauh berbeda dengan kontrol 
negatif yaitu $0,5 \%(0,4 \mathrm{~mm}$ dan $0,36 \mathrm{~mm})$ dan $1 \%(0,44 \mathrm{~mm}$ dan $0,36 \mathrm{~mm})$. Namun demikian, seiring dengan peningkatan konsentrasi yang digunakan yaitu $5 \%$ dan $10 \%$ terjadi perbedaan yang nyata apabila dibandingkan dengan kontrol negatif $((1,05 \mathrm{~mm})$ dan $(1,17 \mathrm{~mm}$ dan $1,42 \mathrm{~mm}))$, terkecuali pada bakteri S. Typhimurium pada tingkat konsentrasi $5 \%(0,57 \mathrm{~mm})$. Hasil pengujian juga menunjukkan tidak adanya perbedaan daya hambat yang ditunjukkan antar kedua jenis bakteri uji pada semua tingkatan konsentrasi yang diberikan.

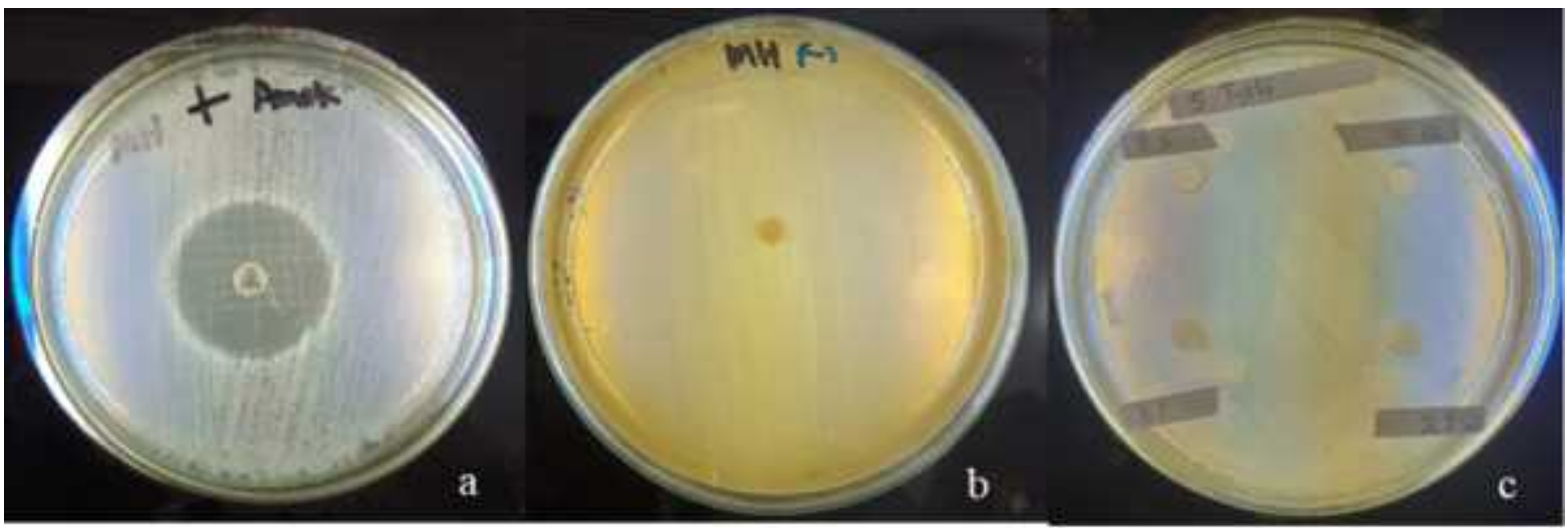

Gambar 3. Zona hambat dari (a), kontrol positif, (b) negatif dan (c), 4 konsentrasi minyak daun jeruk purut terhadap $S$. typhi

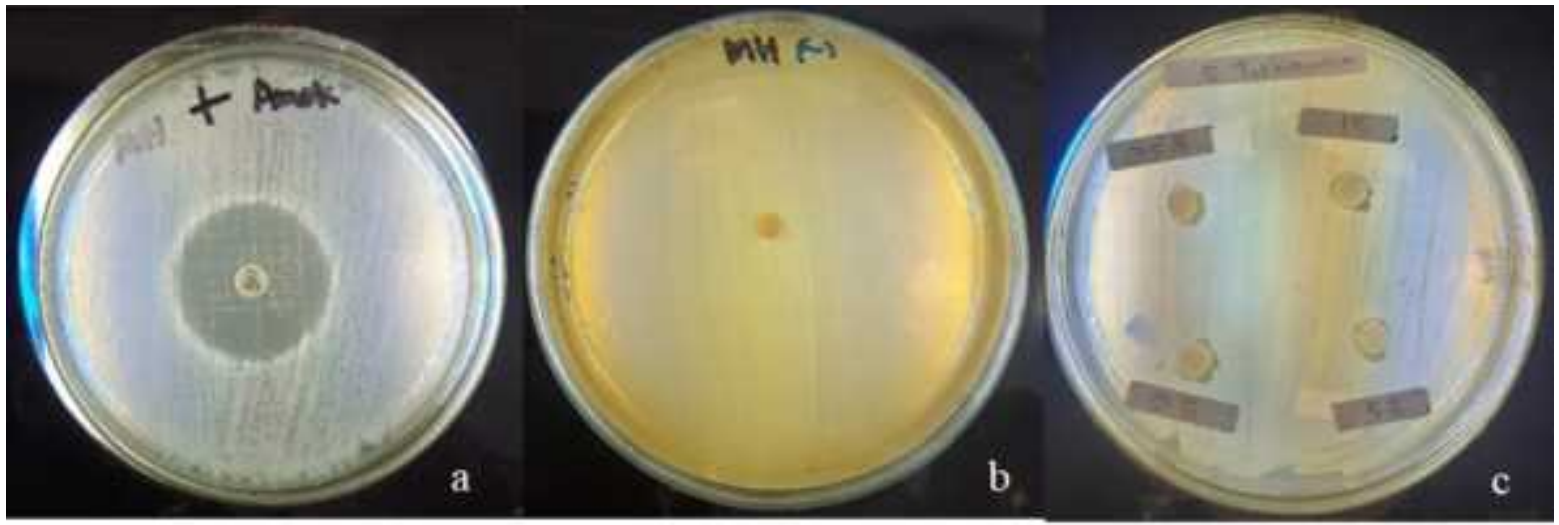

Gambar 4. Zona hambat dari (a), kontrol positif, (b) negatif dan (c), 4 konsentrasi minyak daun jeruk purut terhadap $S$. typhimurium

S. typhi dan S. Typhimurium termasuk golongan bakteri Gram negatif dari genus Salmonella dan menjadi penyebab infeksi penyakit seperti demam tifoid (Jajere, 2019). Bakteri ini tergolong bakteri yang memiliki resisten terhadap bahan antibakteri (Naveed dkk., 2013). Kee-Eng dkk., (2015) melaporkan bahwa bakteri dari kelompok Salmonella tergolong kedalam bakteri dengan sifat MDR (multi drug resistant) karena memiliki resistensi yang cukup tinggi terhadap beberapa jenis antibakteri. Hal ini diduga selain dikarenakan adanya mutasi bakteri yang menyebabkan resistensi juga disebabkan karena resistensi alami yang dimiliki oleh jenis bakteri Gram negatif (Munita dan Arias, 2016; Kapoor dkk., 2017).

Daya hambat yang ditunjukkan oleh minyak atsiri daun jeruk pada bakteri S. typhi maupun $S$. Typhimurium tergolong lemah (Pangestu dkk., 2017), hal ini diduga karena konsentrasi yang digunakan cukup rendah sehingga belum optimal menghambat pertumbuhan bakteri. Namun demikian, daya hambat yang ditunjukkan terhadap bakteri S. Typhimurium pada penelitian ini lebih tinggi dibandingkan yang dilaporkan oleh Hidayanti dkk., (2020) pada bakteri yang sama dengan konsentrasi yang lebih tinggi $(20 \%, 1,17 \mathrm{~mm}$ ) menggunakan minyak daun kari (Murraya koenigii L. Spreng). Dengan demikian, dapat terlihat bahwa minyak atsiri daun jeruk ini memiliki potensi sebagai antibakteri alami. 
Menurut Raho dan Benali (2012) dan Thielmann dkk., (2019), konsentrasi dari minyak atsiri merupakan salah satu faktor penentu dalam menentukan aktivitas antibakteri. Minyak atsiri tergolong kedalam senyawa yang bersifat lipofilik yang akan dapat dengan mudah memasuki sel bakteri dan mengganggu permeabilitas dari sel. Permeabilitas sel yang terganggu ini ditandai dengan kehilangan ion dan energi ATP yang diiringi dengan terjadinya koagulasi dari sitoplasma dan kerusakan pada lipid serta protein sel. Hal ini umumnya terjadi pada penggunaan konsentrasi minyak atsiri yang tinggi (Perricone dkk., 2015; Swamy dkk., 2016). Oleh karena itu, kedepannya perlu dipertimbangkan digunakannya konsentrasi yang lebih tinggi untuk melihat tingkat penghambatannya terhadap bakteri S. typhi dan S. Typhimurium.

Adanya aktivitas antibakteri $S$. typhi dan S. Typhimurium ini menguatkan kajian-kajian yang sebelumnya telah dilakukan dimana tanaman jeruk purut memiliki potensi yang besar sebagai agen antibakteri seperti terhadap bakteri Acinetobacter baumannii (Borusiewicz dkk., 2017) Staphylococcus aureus, Escherichia coli (Yuliani dkk., 2011; Warsito dkk., 2017), Klebsiella pneumoniae (Jamaluddin dkk., 2017), Salmonella typhi, Shigella spp., Salmonella arizonae, Serratia spp., Morganella morganii, Citrobacter spp., Plesiomonas shigelloides, Providencia spp., Yersinia enterocolitica dan Enterobacter spp (Sreepian dkk., 2019). Selain itu, hasil penelitian ini membuktikan adanya potensi antibakteri alami yang dimiliki oleh daun jeruk purut yang tumbuh di Kalimantan Barat khususnya dari minyak atsirinya. Diharapkan dari hasil kajian yang telah dilakukan ini dapat menambah referensi terkait dengan usaha mengembangkan tanaman jeruk purut sebagai salah satu jenis tanaman agroforestri penghasil minyak atsiri di Kalimantan Barat yang dapat diolah menjadi antibakteri alami.

\section{KESIMPULAN}

Minyak atsiri daun jeruk purut teridentifikasi memiliki 12 senyawa, dan 5 senyawa utamanya adalah sitronellal (80,83\%), 2,6-oktadiene (5,36\%), bicyclo (3.1.0) hexane $(3,79 \%)$, sitronellol $(3,48 \%)$ dan linalol $(2,57 \%)$. Aktivitas penghambatan pertumbuhan bakteri $S$. typhi atau $S$. Typhimurium oleh minyak daun jeruk purut tergolong lemah dengan zona hambat yang terbentuk pada konsentrasi maksimum yang diberikan (10\%) sebesar $1,17 \mathrm{~mm}$ dan 1,42 $\mathrm{mm}$. Perlu penelitian lanjutan untuk mengetahui konsentrasi optimum dalam penghambatan pertumbuhan bakteri S. typhi atau $S$. Typhimurium.

\section{DAFTAR PUSTAKA}

Borusiewicz, M., Trojanowska, D., Paluchowska, P., Janeczko, Z., Petitjean, M. W., and Budak, A. (2017). Cytostatic, Cytotoxic, and Antibacterial Activities of Essential Oil Isolated from Citrus hystrix. ScienceAsia, 43(2), pp. 96-106. https://doi.org/10.2306/scienceasia15131874.2017.43.096

Cita, Y. P. (2011). Bakteri Salmonella typhi dan Demam Tifoid. Jurnal Kesehatan Masyarakat, 6(1), pp. 42-46.

Hidayanti, N., Yusro, F., and Mariani, Y. (2020). Bioaktivitas Minyak Atsiri Daun Kari (Murraya koenigii L. Spreng) Terhadap Bakteri Enterococcus faecalis dan Salmonella Tyhpimurium. Bioma. 5 (1), pp. 95-102.

Hua Li., Z., Cai Ming., Shuai Liu Y., Long Sun P., and Lei Luo S. (2019). Antibacterial Activity and Mechanism of Essential Oil From Citrus medica L. var. sarcodacytylis. Molecules. 24, pp. 1-10. https://doi.org/10.3390/molecules24081577.

Jajere S.M. (2019). A Review of Salmonella enterica With Particular Focus on The Pathogenicity and Virulence Factors, Host Specificity and Antimicrobial Resistance Including Multidrug Resistance. Veterinary World. 12 (5), pp. 504-521. https://doi.org/10.14202/vetworld.2019.504-521.

Jamaluddin, N., Pulungan, M. H., and Warsito. (2017). Uji Aktivitas Antibakteri Minyak Atsiri Jeruk Purut (Citrus hystrix DC) terhadap Klebsiella pneumoniae ATCC. Industria: Jurnal Teknologi Dan Manajemen Agroindustri, 6(2), pp. 61-66.

Lestari, S., Jayuska, A., and Indrayani, Y. (2015). Bioaktivitas Minyak Atsiri Daun Jeruk Purut (Citrus hystrix) Terhadap Rayap Tanah (Coptotermes sp.). Jurnal Kimia Khatulistiwa, 4(4), pp. 83-88.

Kee-Eng, S., Pusparajah, P., Syakima Ab. Mutalib, N., Leng Ser, H., Gan Chan, K., and Han Lee, 
H. (2015). Salmonella: A Review on Pathogenesis, Epidemiology and Antibiotic Resistance. $\begin{array}{lllll}\text { Frontiers in } & \text { Life } & \text { 284-293. }\end{array}$ https://doi.org/10.1080/21553769.2015.1051243.

Mayasari, D., Jayuska, A., and Wibowo, M. A. (2013). Pengaruh Variasi Waktu dan Ukuran Sampel terhadap Komponen Minyak Atsiri dari Daun Jeruk Purut (Citrus hystrix DC.). Jurnal Kimia Khatulistiwa, 2(2), pp. 74-77.

Munita, J.M., and Arias, C.A. (2016). Mechanism of Antibiotic Resistance. Microbiol Spectr. 4 (2), pp. 1-37. https://doi.org/10.1128/microbiolspec.VMBF-0016-2015.

Naveed R., Hussain I., Tawab A., Tariq, M., Rahman, M., Hameed, S., Mahmood, M.S., Siddique, AB., and Iqbal, M. (2013). Antimicrobial Activity of the Bioactive Components of Essential Oils from Pakistani Spices Against Salmonella and Other Multi-Drug Resistant Bacteria. BMC Complementary and Alternative Medicine. 265 (13), pp. 1-10. https://www.biomedcentral.com/147 2-68882/13/265.

Kapoor, G., Saigal, S., and Elongavan, A. (2020). Action and Resistance Mechanism of Antibiotics: A Guide for Clinicians. J. Aneesthesiology Clinical Pharmacology. 33 (3), pp. 300-305. https://doi.org/10.4103/joacp.JOACP_349_15.

Kaur, S. P., Rao, R., and Nanda, S. (2011). Amoxicillin: A broad spectrum antibiotic. International Journal of Pharmacy and Pharmaceutical Sciences, 3(3), pp. 30-37.

Raho, B.G., and Benali M. (2012). Antibacterial Activity of Essential Oils from The Leaves of Eucalyptus globulus Against Escherichia coli and Staphylococcus aureus. Asian Pacific Journal of Tropical Biomedicine. 2 (9), pp. 739-742. https://doi.org/10.1016/S22211691(12)60220-2.

Perricone, M., Arace, E., Corbo, M.R., Sinigaglia, M., and Bevilacqua, A. (2015). Bioactivity of Essential Oils: A Review on Their Interaction with Food Components. Frontiers in Microbiology. 6 (76), pp. 1-7. https://doi.org/10.3369/fmicb.2015.00076.

Nur, S., Baitanu, J. A., dan Gani, S. A. (2019). Pengaruh Tempat Tumbuh dan Lama Penyulingan secara Hidrodestilasi terhadap Rendemen dan Profil Kandungan Kimia Minyak Atsiri Daun Kemangi (Ocimum canum Sims L.). Jurnal Fitofarmaka Indonesia, 6(2), pp. 363-367. https://doi.org/10.33096/jffi.v6i2.507.

Pangestu NS., Nurhamidah., dan Elvinawati. (2017). Aktivitas Antioksidan dan Antibakteri Ekstrak Daun Jatropha gossypifolia L. Alotrop. 1 (1), pp. 15-19. https://ejournal.unib.ac.id/index.php/JIPI.

Putri, H., Nagadi, S., Larasati, Y. A., Wulandari, N., dan Hermawan, A. (2013). Cardioprotective and Hepatoprotective Effects of Citrus hystrix Peels Extract on Rats Model. Asian Pacific Journal of Tropical Biomedicine, 3(5), pp. 371-375. https://doi.org/10.1016/S22211691(13)60079-9

Rosiana, N., Feryanto, dan Sinaga, V. R. (2017). Posisi Daya Saing dan Tingkat Persaingan Minyak Atsiri Indonesia di Pasar Global. AGRICORE-Jurnal Agribisnis Dan Sosial Ekonomi Pertanian, 2(1), pp. 205-290.

Sandika, J., dan Suwandi, J. F. (2017). Sensitivitas Salmonella thypi Penyebab Demam Tifoid terhadap Beberapa Antibiotik. Majority, 6(1), 41-45.

Santos, R. L., Tsolis, R. M., Bäumler, A. J., and Adams, L. G. (2003). Pathogenesis of SalmonellaInduced Enteritis. Brazilian Journal of Medical and Biological Research, 36(1), pp. 3-12. https://doi.org/10.1590/s0100-879x2003000100002

Sreepian, A., Sreepian, P. M., Chanthong, C., Mingkhwancheep, T., and Prathit, P. (2019). Antibacterial Activity of Essential Oil Extracted from Citrus hystrix (Kaffir lime) Peels: An In vitro Study. Tropical Biomedicine, 36(2), pp. 531-541.

Sun, S., Phrutivorapongkul, A., Dibwe, D. F., Balachandran, C., and Awale, S. (2018). Chemical Constituents of Thai Citrus hystrix and Their Antiausterity Activity against the PANC-1 Human Pancreatic Cancer Cell Line [Review-article]. Journal of Natural Products, 81(8), pp. 1877-1883. https://doi.org/10.1021/acs.jnatprod.8b00405.

Swamy MK., Aktar MS., and Sinniah UR. (2016). Antimicrobial Properties of Plant Essential Oils Against Human Pathogens and Their Mode of Action: An Updated Review. Evidende-Based Complementary and Alternative Medicine. 12 (20), pp. 1-21. DOI: https://doi.org/10.1155/2016/3012462. 
Tanzil, L., Latirah, dan Nugroho, P. D. (2017). Antidandruff Activity of Extracts from Kaffir Lime (Citrus hystrix DC.) Prefered by Different Solvents. Sanitas: Jurnal Teknologi Dan Seni Kesehatan, 8(1), pp.57-62.

Thielmann, J., Muranyi, P., and Kazman, P. (2019). Screening Essential Oils for Their Antimicrobial Activities Againts The Foodborne Pathogenic Bacteria Escherichia coli and $\begin{array}{lllll}\text { Staphylococcus } & \text { aureus. } & \text { Heliyon. } & \text { 5(6), } & \text { 1-6. }\end{array}$ https://doi.org/10.1016/j.heliyon.2019.e01860.

Wahyudi. (2013). Buku Pegangan Hasil Hutan Bukan Kayu (W. Syafii, ed.). Pohon Cahaya, Yogyakarta.

Warsito, Noorhamdani, Sukardi, dan Suratmo. (2017). Aktivitas Antioksidan dan Antimikroba Minyak Jeruk Purut (Citrus hystrix DC.) dan Komponen Utamanya. Journal of Enviromental Engineering and Sustainable Technology, 4(1), pp. 13-18. https://doi.org/10.21776/ub.jeest.2017.004.01.3

Wei Su. P., Hong Yang .C., Ferng Yang. J., Yu Su .P., and Chuang L.Y. (2015). Antibacterial Activities and Antibacterial Mechanism of Polygonum cuspidatum Extarcts Against Nosocomial Drug-Resistant Pathogens. Moleculs. 2015(20), pp. 11119-111130. DOI: https://doi:10.3390/molecules200611119.

Yuliani, R., Indrayudha, P., Septi, D., dan Rahmi, S. (2011). Aktivitas Antibakteri Minyak Atsiri Daun Jeruk Purut (Citrus hystrix) terhadap Staphylococcus aureus dan Escherichia coli. Pharmacon, 12(2), 50-54. 